\title{
ISOLASI SELULOSA DARI BAGAS TEBU MELALUI PEMANASAN IRADIASI GELOMBANG MIKRO
}

\author{
Isolation of Cellulose From Sugarcane Bagasse Through Heating of Microwave Irradiation \\ Jufrinaldi \\ Program Studi Teknik Kimia, Fakultas Teknik, Universitas Pamulang 45363 Pamulang, Tangerang Selatan \\ Jl Surya Kencana No.1, Tangerang Selatan, BANTEN \\ Email : Jufrinaldikoto@gmail.com
}

\begin{abstract}
ABSTRAK
Di Indonesia, bagas tebu berpotensi sebagai sumber alternatif selulosa karena jumlahnya yang melimpah. Bagas tebu merupakan hasil samping dari proses pembuatan gula yang mengandung 40-50\% selulosa dan 25-35\% hemiselulosa. Selulosa berpotensi dikembangkan menjadi salah satu bahan baku kimia terbarukan. Potensi tersebut ditunjang dengan sifatnya yang biokompatibilitas, dan sifat ramah lingkungannya. Penelitian ini bertujuan untuk menghasilkan selulosa melalui proses likuifaksi, delignifikasi dan pemutihan menggunakan pemanas gelombang iradiasi mikro. Isolasi selulosa dari bagas tebu memanfaatkan pemanasan iradiasi gelombang mikro selama 18 menit. Isolat selulosa yang dihasilkan menunjukkan rendemen sebesar $38.57 \%$ dengan kadar $\alpha$-selulosa dan hemiselulosa berturut-turut adalah $78.46 \%$ dan $18.65 \%$. Keberhasilan proses isolasi juga dapat dilihat dari spektrum FTIR bagas tebu dan isolat selulosa. Hasil spektrum selulosa menunjukkan pengurangan serapan gugus guasil dam siringil, dan peningkatan serapan gugus $\beta$-selulosa. Pencirian isolat selulosa juga dilakukan menggunakan DSC dan SEM yang menunjukkan keberhasilan proses isolasi selulosa. Pemanasan menggunakan gelombang irradiasi mikro dapat mengurangi waktu proses. Hal ini mengindikasikan bahwa gelombang irradiasi mikro dapat diaplikasikan untuk efektivitas waktu proses.
\end{abstract}

Kata kunci : sellulosa, isolasi, gelombang irradiasi mikro, bagas tebu.

\begin{abstract}
Sugarcane bagasse is abundant in Indonesia thus potential as an alternative source of cellulose. Sugarcane bagasse is a byproduct of sugar extracting process in producing sugar containing $40-50 \%$ of cellulose and $25-35 \%$ of hemicellulose. Cellulose is potential to be developed into a renewable chemical raw material. This potency is supported by biocompatibility and eco-friendly. The aims of this research to get cellulose from sugarcane bagasse through liquifaction, delignification, and bleaching using microwave irradiation. The isolation of cellulose of sugarcane bagasse was carried out by microwave irradiation for 18 minutes. The yield of the process was $38.57 \%$. It contained $\alpha$-cellulose and hemicellulose $78.46 \%$ and $18.65 \%$, respectively. The isolation process result can be seen from the FTIR spectrum of the sugarcane bagasse and the isolated cellulose. The spectrum showed the reduction of guaiacyl and syringil groups absorption and the increase of $\beta$-glycosidic bonds absorption. The isolation of cellulose is also studied through DSC and SEM, which is performed to evaluate the success of the isolation. In this study, microwave irradiation method has successfully managed to reduce the processing time. This indicates that microwave irradiation can be applied to improve the effectiveness of time
\end{abstract}

Keywords : cellulose, isolation, irradiation microwave, sugarcane bagasse 


\section{PENDAHULUAN}

Tanaman tebu telah dimanfaatkan untuk memproduksi gula dari zaman Belanda hingga sekarang. Pada tahun 2012, Luas perkebunan tebu di Indonesia mencapai 375 ribu hektar yang tersebar di Medan, Lampung, Solo, Tegal, dan Mojokerto. Proses produksi gula dari tanaman tebu akan menghasilkan 5\% molase, 5\% air, dan $90 \%$ sisa proses pembuatan gula tebu berupa ampas tebu atau bagas [1]. Limbah proses pembuatan gula tebu biasanya hanya dimanfaatkan sebagai bahan bakar, bahan pembuat pulp kertas, pupuk organik dan pakan ternak. Namun demikian, limbah bagas tebu ini masih belum terberdayakan secara maksimal sehingga perlu dilakukan pengolahan lain yang lebih bermanfaat dari limbah sisa proses pembuatan tebu tersebut.

Pembaharuan limbah mendapatkan perhatian yang semakin besar dalam kebutuhan global untuk konservasi lingkungan saat ini [2]. Hal inilah yang menjadi fokus dalam pengolahan sisa produksi pembuatan gula tebu. Dilihat dari komposisinya, secara umum bagas tebu mengandung 40-50\% polimer selulosa, 25$35 \%$ hemiselulosa yang tersusun atas xilosa, arabinosa, galaktosa, glukosa, dan manosa, sisanya berupa lignin serta beberapa mineral, lilin, dan senyawa lainnya [3]. Banyaknya kandungan selulosa menjadikan bagas tebu sebagai sumber selulosa yang cukup melimpah di Indonesia. Selulosa berpotensi dikembangkan menjadi salah satu bahan baku kimia terbarukan. Potensi tersebut ditunjang dengan ketersediaan selulosa yang melimpah di alam, biokompatibilitas, dan sifat ramah lingkungannya [4].

Selulosa berpotensi dikembangkan menjadi salah satu bahan baku kimia terbarukan. Potensi tersebut ditunjang dengan ketersediaan selulosa yang melimpah di alam, biokompatibilitas, dan sifat ramah lingkungannya [4]. Selulosa banyak digunakan dalam berbagai bidang, seperti penyalut, membran, farmasi, dan bahan makanan [5], produksi bioetanol [6], metana, energi [7], pulp [8], 5-hidroksimetil furfural [9], dan digunakan pada pembalut kewanitaan [10].

Berbagai kajian tentang isolasi selulosa dari telah dilakukan seperti perlakuan alkali dan asam [10] (Purwaningsih 2012), kombinasi liquifaksi, alkali dan klorit [11], enzimatik[12], cairan ionik [13], ledakan uap [14]. Dari berbagai metode tersebut pemanasan yang digunakan masih bersifat konvensional kecuali pada proses liquifaksi yang sudah menggunakan metode pemanasan iradiasi gelombang mikro. Metode pemanasan iradiasi gelombang mikro digunakan agar dapat mereduksi waktu proses dan menyediakan panas lebih efisien [15]. Karena belum adanya pemanasan iradiasi gelombang mikro yang digunakan dalam pengisolasian, maka peneliti mencoba menggunakan pemanasan iradiasi gelombang mikro dalam proses liquifaksi, perlakuan alkali dan asam.

\section{BAHAN DAN METODE}

\section{Bahan}

Bahan yang digunakan, yaitu bagas tebu yang berasal dari pabrik gula di Tegal, pelet $\mathrm{NaOH}$ (Merck), metanol p.a (Merck), gliserol (Bratachem, Indonesia), H2SO4 96\% (Merck), H2O2 50\% (Bratachem, Indonesia), akuades.
Alat
Alat yang digunakan adalah peralatan gelas, oven, microwave, dan peralatan yang digunakan pada tahap pencirian seperti spektrofotometer FTIR (IR Prestige-21 Shimadzu, Pusat Kimia LIPI Serpong), 
scanning electron microscope (SEM) (JSM6510, Nanotech Herbal Indonesia;), differential scanning calorimetry (DSC) (Perkin Elmer, BATAN Serpong),Uji komponen kimia.

\section{Isolasi selulosa}

Isolasi selulosa bagas tebu dimulai dengan proses liquifaksi[11]. Bagas tebu kering digiling sampai berukuran 60 mesh. 10 gram bagas tebu, $150 \mathrm{ml}$ pelarut (gliserolmetanol:2/1) dan asam Sulfat $1.75 \%$ (15,25,35 ml sebagai ISL1, ISL2, ISL3) secara berturut-turut ditambahkan kedalam gelas piala. Selanjutnya campuran dipanaskan ke dalam alat microwave selama 3 menit. Campuran disaring dan dinetralkan dengan metanol dan dikeringkan. Tahap delignifikasi dan bleaching yang dilakukan merujuk pada [16], pemanasan yang digunakan secara konvensional diganti dengan gelombang iradiasi mikro. Residu ditambahkan $\mathrm{NaOH}$ 4\% (1g:19 ml) dan dipanaskan dalam alat microwave dengan variasi waktu 1,2, dan 3 menit (D1,D2 dan D3). Campuran kemudian disaring dengan pompa vakum, residu yang didapatkan dicuci dengan aquadest hingga $\mathrm{pH}$ filtrat tidak berubah kemudian dikeringkan pada suhu $50^{0} \mathrm{C}$ hingga bobot konstan. Bagas tebu hasil delignifikasi ditambahkan $\mathrm{H}_{2} \mathrm{O}_{2} 5 \% \mathrm{pH} 12$ (1g:25 ml), dipanaskan dalam alat microwave selama 4 menit kemudian disaring dan endapannya dicuci dengan aquadest sampai pH netral. Perlakuan dengan larutan peroksida diulang 2 kali dengan waktu yang sama. Produk hasil bleaching dikeringkan dalam oven pada suhu $60^{\circ} \mathrm{C}$ hingga bobot konstan. Bagas tebu dan selulosa hasil pemutihan dilakukan pencirian terhadap komponen kimianya untuk mengetahui kadar $\alpha$-selulosa, hemiselulosa, lignin, analisis gugus fungsi dengan spektrometer FTIR (Fourier Transform Infrared), analisis termal
DSC (Differential Scanning Calorimetry) dan analisis morfologi permukaan dengan SEM (Scanning Electron Microscope).

\section{HASIL DAN PEMBAHASAN}

\section{Isolat Selulosa dari Bagas Tebu}

Berbagai studi tentang isolasi selulosa mengatakan adanya kesulitan untuk mendapatkan selulosa murni [17] sehingga isolat yang diperoleh berupa selulosa dalam bahan kasar $\alpha$-selulosa. Isolasi selulosa dari bagas tebu pada penelitian ini melewati beberapa tahap, yaitu proses liquifaksi, delignifikasi, dan bleaching. Metode pemanasan yang digunakan dalam proses liquifaksi, delignifikasi dan bleaching dalam penelitian ini adalah melalui iradiasi gelombang mikro. Pemanasan melalui iradiasi gelombang mikro adalah salah satu teknik yang berpotensi bagus karena menyediakan proses pemanasan volumetrik pada peningkatan efisiensi pemanas, mudah dioperasikan secara elektronik, waktu reaksi cepat dan sifatnya yang highly reproducible [15]. Pemanasan konvensional pada suhu tertentu memerlukan waktu yang lebih lama dan banyak sehingga kurang efektif dan efisien. Proses liquifaksi menggunakan asam sulfat dapat mengaktifkan atom oksigen pada ikatan glikosidik pada rantai selulosa dan lignin dengan selulosa [11] sehingga mempermudah dalam proses delignifikasi dan meningkatkan kemurnian selulosa. Pada proses delignifikasi terjadi pemutusan ikatan antara lignin dengan selulosa dan menghilangkan lignin. Purwaningsih [16] melaporkan larutan $\mathrm{NaOH}$ dapat menghilangkan lignin sebesar 60\%. Skema reaksi komplek karbohidrat-lignin dengan $\mathrm{NaOH}$ disajikan pada Gambar 1 yang memperlihatkan pemutusan ikatan ester antara karbohidrat dengan lignin. 


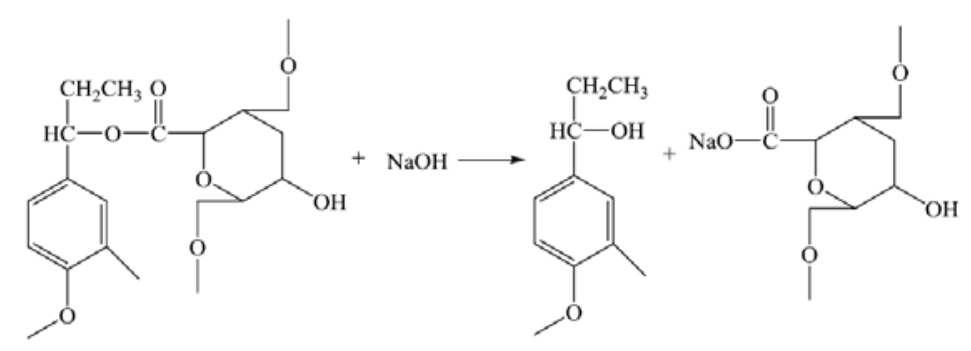

Gambar 1. Skema reaksi kompleks karbohidrat lignin dengan NaOH[18]

Pada umumnya metode delignikasi konvensional yang digunakan adalah menggunakan natrium klorit $(\mathrm{NaOCl})$ dalam suasan asam. Namun penggunaan natrium klorit dapat menimbulkan masalah terhadap lingkungan karena senyawa klorin dan turunannya dapat menghasilkan beberapa senyawa lain yang terklorinasi sehingga menyebabkan masalah yang serius terhadap lingkungan. Oleh karena itu digunakan asam peroksida $\left(\mathrm{H}_{2} \mathrm{O}_{2}\right)$ dalam suasana basa sebagai pereaksi delignifikasi. $\mathrm{H}_{2} \mathrm{O}_{2}$ merupakan senyawa oksidator kuat sehingga dapat digunakan pada proses pemucatan (bleaching) dan delignifikasi. $\mathrm{H}_{2} \mathrm{O}_{2}$ lebih mudah terurai jika dilarutkan dalam media basa menghasilkan anion peroksida dan air, seperti reaksi dibawah ini.

$$
\mathrm{H}_{2} \mathrm{O}_{2}+\mathrm{HO}^{-} \rightarrow \mathrm{HOO}^{-}+\mathrm{H}_{2} \mathrm{O}
$$

Anion peroksida (HOO-) merupakan spesi aktif yang berperan penting dalam penghilangan gugus kromofor lignin. Anion peroksida bersifat nukleofilik kuat yang akan menyerang gugus etilena dan karbonil pada molekul lignin dan mengubahnya menjadi spesi yang tidak mengandung kromofor. Perlakuan dengan $\mathrm{H}_{2} \mathrm{O}_{2}$ dalam media basa juga dapat meningkatkan $\mathrm{pH}$ reaksi sehingga dapat digunakan untuk melarutkan sebagian besar hemiselulosa, selain berfungsi sebagai pereaksi pada proses delignifikasi dan pemucatan [19].

Bagas tebu yang mengalami berbagai perlakuan mengalami perubahan tekstur dan warna (Gambar 3). Bagas tebu yang telah melewati proses liquifaksi teksturnya menjadi lebih lembut (B). Kemudian setelah melewati proses delignifikasi dengan $\mathrm{NaOH}$ berubah menjadi lebih keras (C). Tekstur yang lebih keras disebabkan oleh terbukanya bagian kristalin selulosa sehingga rongga kosong pada serat selulosa akan runtuh yang menyebabkan bahan menjadi lebih padat. Menurut Stevens [20], ion-ion hidroksida dari $\mathrm{NaOH}$ diikat oleh ikatan hidrogen sehingga terbentuk interaksi baru yang lebih kuat antara gugus hidroksil selulosa dan $\mathrm{NaOH}$ yang membuka bagian kristalin selulosa. Produk delignifikasi dan pemucatan dengan $\mathrm{H}_{2} \mathrm{O}_{2}$ menghasilkan serat yang lebih keras jika dibandingkan dengan produk sebelumnya, yaitu hasil delignifikasi dengan $\mathrm{NaOH}$.

Perubahan warna bagas yang mengalami perlakuan ditampilkan pada Gambar 2. Perlakuan Liquifaksi menyebabkan warna dari kuning kecoklatan menjadi coklat kemerahan (B). Hal ini mengindikasikan bahwa atom $\mathrm{O}$ pada ikatan glikosidik telah teraktifkan. Setelah melewati proses delignifikasi warnanya menjadi kuning kehijauan (C) karena pada proses ini sebagian lignin sudah hilang. Proses 


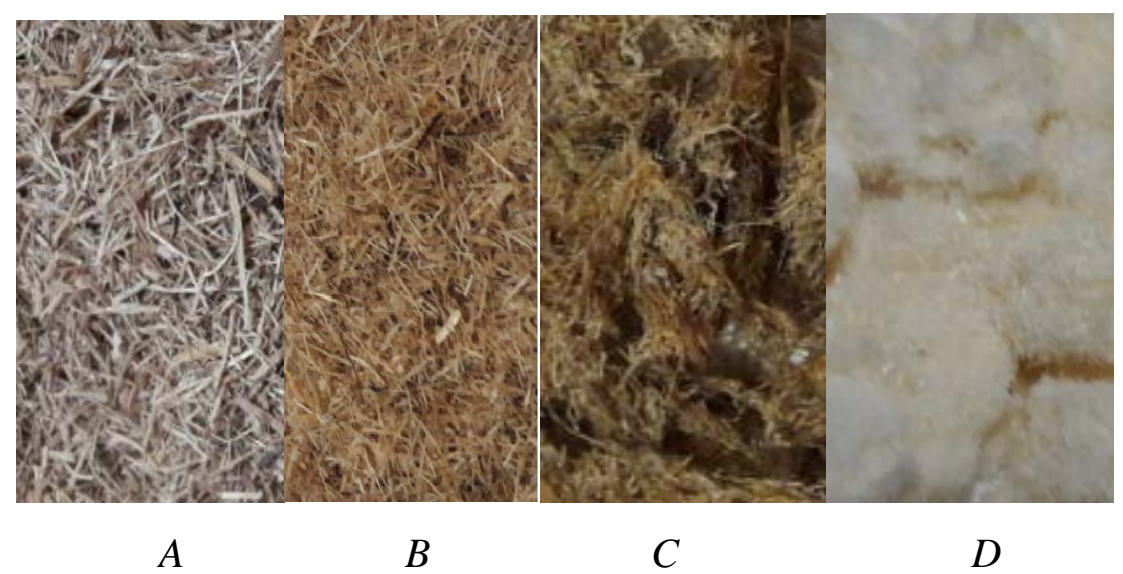

Gambar 3. (A) Bagas tebu (B) Bagas tebu perlakuan liquifaksi (C) Bagas tebu perlakuan delignifikasi (D) Bagas tebu perlakuan bleaching.

pemucatan menjadikan serat menjadi lebih pucat berwarna putih kekuningan (D) yang menandakan hemiselulosa dan lignin semakin berkurang pada bahan.

\section{Evaluasi Keberhasilan Tahap isolasi}

Berbagai studi tentang isolasi selulosa mengatakan adanya kesulitan untuk mendapatkan selulosa murni [17] sehingga isolat yang diperoleh berupa selulosa dalam bahan kasar $\alpha$-selulosa, yaitu selulosa yang tidak larut dalam $\mathrm{NaOH}$ pekat. Evaluasi keberhasilan tahap isolasi ini dapat dilihat dari rendemen hasil isolat, peningkatan kadar $\alpha$-selulosa dan penurunan kadar lignin.

Komponen Kimia. Analisis komponen kimia pada isolat selulosa dari bagas tebu adalah salah satu indikator keberhasilan tahap isolasi. Evaluasi keberhasilan isolasi ditandai dengan peningkatan kadar $\alpha$ selulosa, dan adanya penurunan kadar lignin dan hemiselulosa secara signifikan. Hasil isolasi dapat dilihat pada Gambar 2.Keberhasilan proses isolasi menggunakan iradiasi gelombang mikro dievaluasi berdasarkan penurunan kandungan lignin dari bahan awalnya. Kandungan lignin pada isolat selulosa ISL3D2 (Volume asam sulfat $35 \mathrm{ml}$, delignifikasi 3 menit) mengalami penurunan dari $19.91 \%$ menjadi $1.95 \%$. kadar lignin yang tertinggal pada isolat ini lebih tinggi dari yang dilaporkan oleh Purwaningsih [16] yaitu $0.19 \%$ tetapi lebih kecil dibandingkan dengan [19] yaitu 3.86\%. Penurunan kadar lignin selama proses delignifikasi menyebabkan peningkatan kadar alfa selulosa yaitu dari 55,77\% menjadi $78.46 \%$. Hasil ini lebih tinggi dibandingkan dengan Purwaningsih [16] yaitu sebesar $77.47 \%$. Tingginya kemurnian selulosa yang didapatkan pada penelitian ini karena adanya perlakuan awal yaitu proses liquifaksi.

Kajian gugus Fungsi. Selain dari analisis komponen kimia, keberhasilan isolasi ini juga dapat dipantau dari hasil spektroskopi inframerah ditunjukkan pada Gambar 4. Interpretasi spektrum dapat dilihat pada Tabel 1.

Spektrum FTIR bahan baku bagas tebu menunjukkan adanya serapan pada $1512 \mathrm{~cm}^{-1}$ mengindentifikasi vibrasi guasil lignin dan cincin lignin, seapan pada $1722 \mathrm{~cm}^{-1}$ untuk vibrasi gugus asetil ester [21], serapan pada $1240 \mathrm{~cm}^{-1}$ untuk gugus siringil pada lignin [22] dan serapan pada $831 \mathrm{~cm}^{-1}$ untuk O-H 


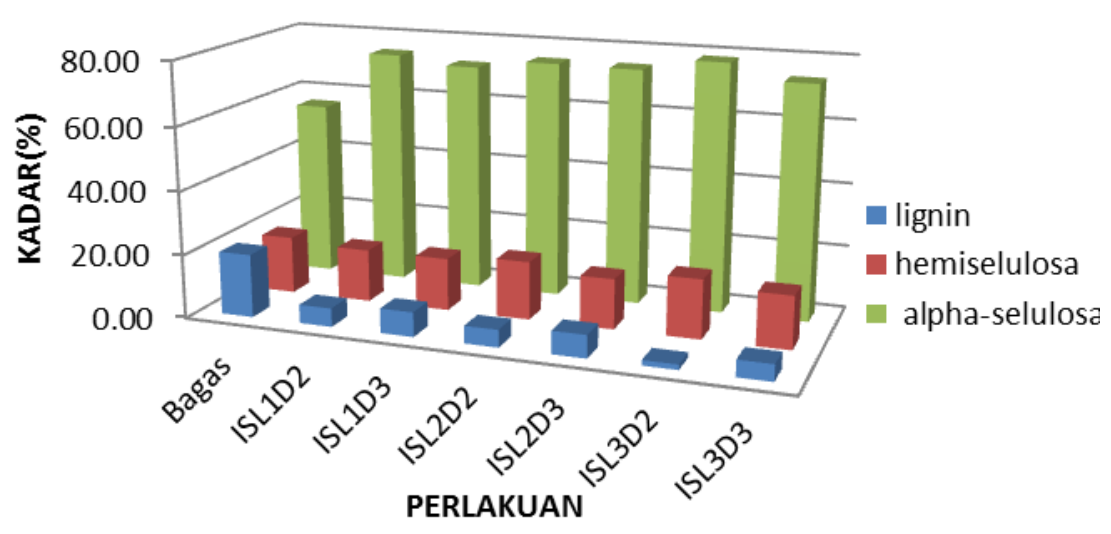

Gambar 2. Hasil uji komponen kimia pada isolat selulosa.

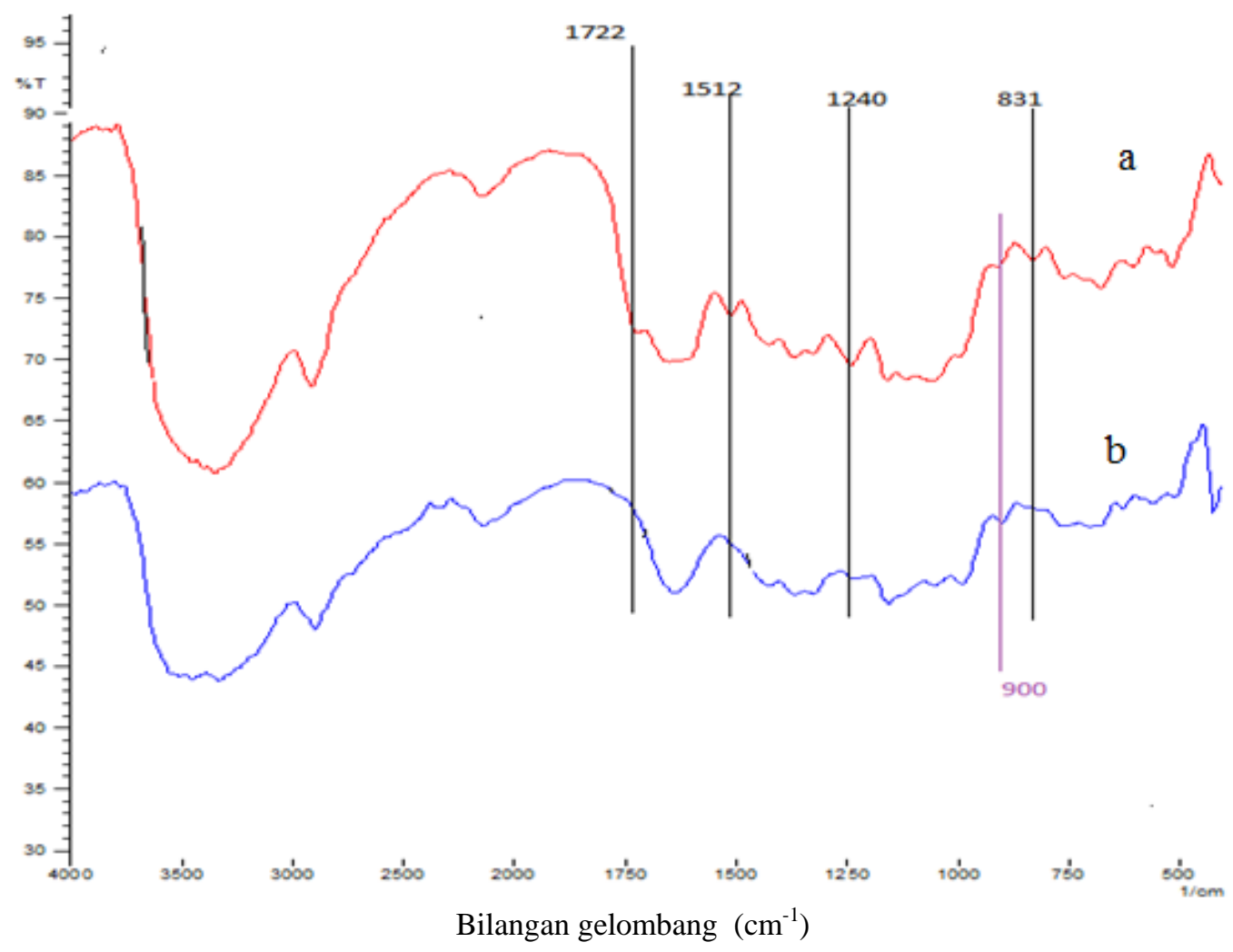

Gambar 4. Spektrum FTIR (a) Bagas tebu dan (b) Isolat selulosa.

tekuk gugus siringil dari senyawa lignin [23]. Setelah perlakuan alkali pada bagas tebu, serapan khas untuk senyawa lignin semakin berkurang dan munculnya serapan khas untuk ikatan beta-glikosida selulosa pada 900 $\mathrm{cm}^{-1}$ yang cukup tajam. Adanya serapan pada bilangan gelombang 1425-1317 $\mathrm{cm}^{-1}$ menunjukkan vibrasi tekuk gugus $\mathrm{CH}_{2}$ [24], vibrasi gugus $\mathrm{O}-\mathrm{H}$ ulur berada pada serapan $3348 \mathrm{~cm}^{-1} \quad$ [25],serapan $2891 \mathrm{~cm}^{-1}$ mengidentifikasi vibrasi ulur gugus C-H [26], pada bilangan gelombang $1240 \mathrm{~cm}^{-1}$ [27] diprediksikan vibrasi gugus $\mathrm{O}-\mathrm{H}$ tekuk pada bidang selulosa, serapan $1161 \mathrm{~cm}^{-1}$ menunjukkan vibrasi ulur gugus C-O [3]. 
Tabel 1. Serapan vibrasi bagas tebu dan selulosa bagas tebu.

\begin{tabular}{|c|c|c|c|c|}
\hline \multirow[b]{2}{*}{ no } & \multicolumn{2}{|c|}{$\begin{array}{c}\text { Bilangan } \\
\text { Gelombang }\left(\mathrm{cm}^{-1}\right)\end{array}$} & \multirow[b]{2}{*}{ Gugus Fungsi } & \multirow[b]{2}{*}{ Acuar } \\
\hline & $\begin{array}{c}\text { Bagas } \\
\text { Tebu }\end{array}$ & $\begin{array}{c}\text { Selulosa } \\
\text { Bagas } \\
\text { Tebu }\end{array}$ & & \\
\hline 1 & 3348 & 3325 & $\mathrm{O}-\mathrm{H}$ ulur & {$[25]$} \\
\hline 2 & 2908 & 2891 & C-H ulur & {$[26]$} \\
\hline 3 & 1722 & $\mathrm{Td}$ & $\begin{array}{c}\text { Karboksil lignin dan gugus } \\
\text { asetil ester }\end{array}$ & {$[21]$} \\
\hline 4 & 1653 & 1637 & $\mathrm{H}_{2} \mathrm{O}$ terjerap & {$[28]$} \\
\hline 5 & 1512 & $\mathrm{Td}$ & $\begin{array}{l}\text { vibrasi guasil dan cincin } \\
\text { lignin }\end{array}$ & {$[21]$} \\
\hline 6 & 1427 & 1425 & $\mathrm{CH}_{2}$ gunting & [29] \\
\hline 7 & 1369 & 1367 & $\mathrm{C}-\mathrm{H}$ asimetrik atau $\mathrm{O}-\mathrm{H}$ tekuk & {$[26]$} \\
\hline 8 & 1327 & 1325 & C-C atau C-O & {$[26]$} \\
\hline 9 & 1240 & Td & gugus siringil pada lignin & {$[22]$} \\
\hline 10 & $\mathrm{Td}$ & 1213 & $\begin{array}{l}\text { Gugus samping } \mathrm{OH} \text { tekuk } \\
\text { yang terikat pada cincin } \\
\text { selulosa }\end{array}$ & {$[27]$} \\
\hline 11 & 1159 & 1157 & -CO antiasimetrik & {$[30]$} \\
\hline 12 & 1060 & 1051 & C-O-C dari cincin piranosa & {$[26]$} \\
\hline 13 & 910 & 900 & ikatan beta-glikosida selulosa & {$[24]$} \\
\hline 14 & 831 & $\mathrm{Td}$ & O-H tekuk gugus siringil & [23] \\
\hline
\end{tabular}

Morfologi permukaan. Teknik SEM merupakan salah satu teknik yang dapat digunakan untuk melihat morfologi permukaan pada beberapa jenis polimer termasuk selulosa. Morfologi permukaan isolat selulosa yang dihasilkan dari penelitian ini terlihat pada gambar 5. Hasil analisis
SEM menunjukkan bahwa mikrograf selulosa yang diisolasi dari bagas tebu berbentuk serat. Diameter selulosa berkisar antara 15-20 $\mu \mathrm{m}$, dengan panjang serat berkisar $100 \mu \mathrm{m}-1 \mathrm{~mm}$ [31], serat selulosa sering menggumpal sehingga ukuran seratnya terlihat lebih besar [32]. 


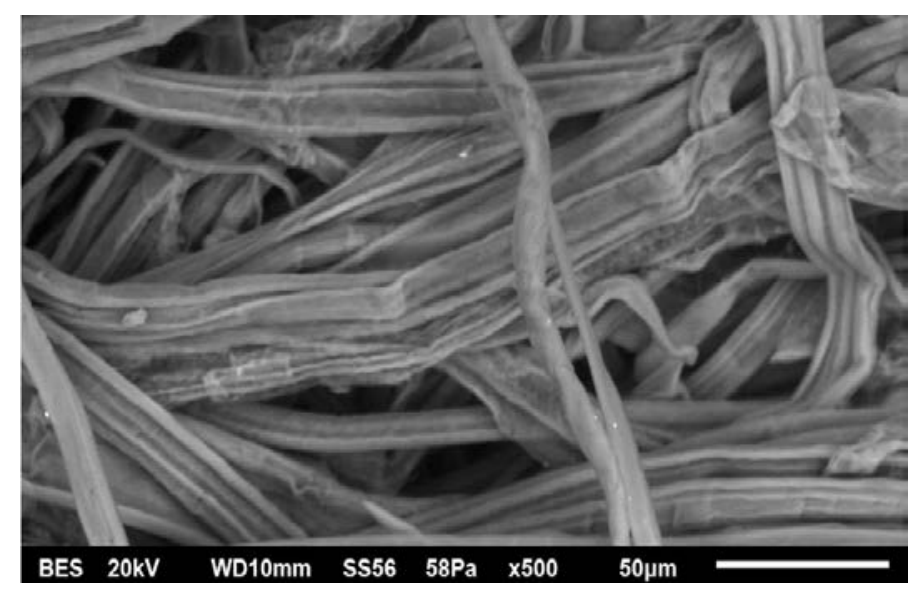

Gambar 5. Morfologi Selulosa

Hasil Analsisis Termal. Analisis termal yang digunakan pada penelitian ini menggunakan alat DSC yang prinsipnya mengukur perbedaan kalor yang masuk ke dalam sampel dengan pembanding sebagai fungsi suhu. Pada termogram hasil analisa DSC (Gambar 6), terdapat puncak pada $64.77^{\circ} \mathrm{C}$ dengan nilai perubahan entalpi sebesar $88.26 \mathrm{~J} / \mathrm{g}$ yang menunjukkan tahap dehidrasi karena sampel masih mengandung air. Pada suhu $337.01^{\circ} \mathrm{C}$ selulosa terdekomposisi maksimum dengan nilai perubahan entalpi sebesar $26.05 \mathrm{~J} / \mathrm{g}$. Nilai dekomposisi yang didapatkan pada penelitian ini lebih rendah dari pada Purwaningsih [12] yaitu $349^{\circ} \mathrm{C}$. Purwaningsih [12] melaporkan dekomposisi selulosa terjadi melalui 3 tahap yaitu dehidrasi molekul air yang teradsorpsi (kurang dari $200^{\circ} \mathrm{C}$ ), dekarboksilasi atau putusnya rantai selulosa $\left(200-400^{\circ} \mathrm{C}\right)$, dan dekarbonasi (lebih dari $400^{\circ} \mathrm{C}$ ).

Isolasi selulosa dari bagas tebu telah dilakukan dengan pemanasan metode iradiasi gelombang mikro pada tahap liquifaksi, delignifikasi dan bleaching dengan waktu proses 18 menit. Hasil isolasi yang diperoleh pada penelitian menunjukan tidak ada perbedaan yang signifikan dengan hasil yang didapatkan pada pemanasan metode konvensional.

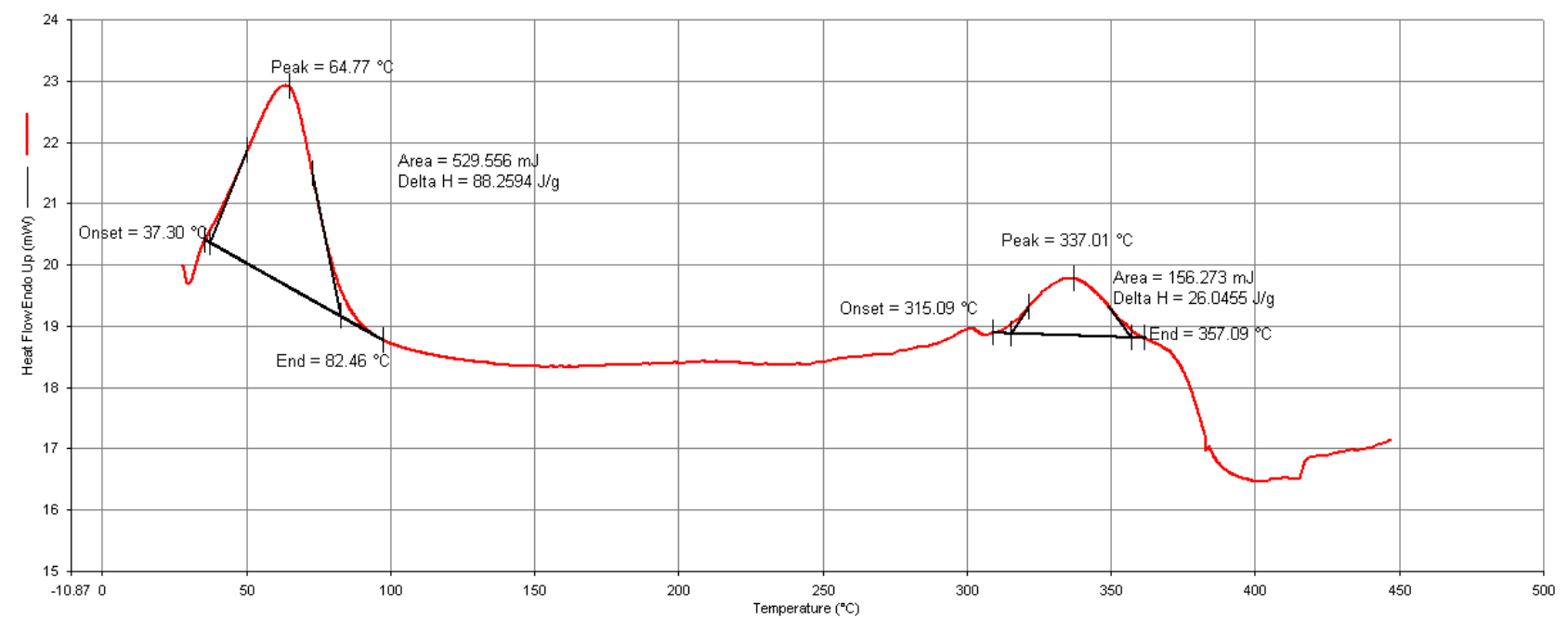

Gambar 6. Termogram DSC isolat selulosa 


\section{Saran}

Pada penelitian ini, proses bleaching diberhentikan ketika isolat sudah menjadi bubur, hendaknya dilakukan penelitian lebih lanjut untuk meneliti kondisi optimalnya

\section{DAFTAR PUSTAKA}

[1] Laula NLA, Nugraha A. 2013. Pemanfaatan Limbah Ampas Tebu Melalui Desain Produk Perlengkapan Rumah. J Tingk Sarjana Senirupa dan Desain. 1: 1-7

[2] Song Y, Zhou J, Zhang L, Wu X. 2008. Homogenous modification of cellulose with acrylamide in $\mathrm{NaOH} /$ urea aqueous solutions. Carbohyd Polym. 73:18-25.

[3] Sun JX, Sun XF, Zhao H, Sun RC. 2004. Isolation and characterization of cellulose from sugarcane bagasse. Jour Polymer Degrab Stab. 84:331339

[4] Ekebafe LO, Ekebafe MO, Akpa FAO, Erhuanga G, Etiobhio BW. 2011. Graft copolymerization of acrylonitrile onto delignified native bamboo (Bambusa vulgaris) cellulosic and its utilization potential for heavy metal uptake from aqueous medium. CI \& CEQ. 17(2):133-140.

[5] Klemm D, Kramer F, Moritz S, Lindstrom T, Ankerfors M, Gray D, Dorris A. 2011. Nanocelluloses: a new family of natur-based materials. Angew Chem Int. 50: 5438-5466

[6] Mervate AA, Ragab AME, EL-Gendy NS , Farahat LA, Madian HR. 2013. Effect of different pretreatments on egyptian sugar-cane bagasse saccharification and bioethanol production. Egypt Jour of Petrol. 22:161-167
[7] Rabelo SC, Carrere H , Filho RM, Costa AC. 2011. Production of bioethanol, methane and heat from sugarcane bagasse in a biorefinery concept. Biores Tech. 102:7887-7895

[8] Pereira LN, Gurgel LVA, Marazebi K, Curvelo AAS. 2011. Delignification of sugarcane bagasse using glycerolwater mixtures to produce pulps for saccharification. Biores Tech. 102:10040-10046.

Doi:10.1016/j.biortech. 2011.08.050

[9] Agustin MB, Nakatsubo F, Yano H. 2016. The thermal stability of nanocellulose and its acetates with different degree of polymerization. Cellul. 23: 451-464.

[10] Yadav S, Illa MPA, Rastogi T, Sharma CS. 2016. High absorbency cellulose acetate electrospun nanofibers for feminine hygiene application. Applied Materials Today.4:62-70. Doi:10.1016/j.apmt.2016.07.002

[11] Xie JX, Yun CY, De Hoop CF, Hu T, Qi J, Shupe TF. 2016. Isolation and characterization of cellulose nanofibers from bamboo using microwave liquefaction combined with chemical treatment and ultrasonication. Carbohyd Polym. doi:10.1016/j.carbpol.2016.06.011, forthcoming.

[12] Tibolla H, Pelissari FM, Menegalli FC. 2014. Cellulose nanofibers produced from banana peel by chemical and enzymatic treatment. LWT-Food Scien and Tech. 59:13111318.

[13] Han QZ, Hou CJ, French AD, Han GP, Wu QL. 2013. Characterization of cellulose II nanoparticles regenerated from 1-butyl-3-methylimidazolium chloride. Carbohid Polym. 94, 773781 
[14] Chirayil CJ, Joy J, Mathew L, Mozetic M, Koetz, Thomsa S. 2014. Isolation and characterization of cellulose nanofibrils from helicteres isora plant. Indust Crops and Products. 59: 27-34.

[15] Sen G, Mishra S, Rani GU, Rani P, Prasad R. 2012. Microwave initiated synthesis of polyacrylamide grafted psyllium and its application as flocculant. Int Jour Biol Macromol 50: 369-375.

[16] Purwaningsih H. 2012. Rekayasa biopolimer dari limbah pertanian berbasis selulusa dan aplikasinya sebagai material separator [Disertasi]. Bogor (ID):Institut Pertanian Bogor.

[17] Sun RC, Tomkinson J, MaPL, Liang SF. 2000. Comparative study of hemicelluloses from rice straw by alkali and hydrogen peroxide treatment. Carbohyd Polym. 42:111122.

[18] Tong CC, Hamzah NM, 1989. Delignification pretreatment of palmpress fibres by chemical method. Pertanika. 12:399-403.

[19] Sun JX, Sun XF, Zhao H, Sun RC. 2004. Isolation and Characterization of Cellulose from Sugarcane Bagasse. J Polymer Degrab Stab. 84:331-339

[20] Stevens MP. 2007. Kimia Polimer. Sopyan I, penerjemah. Jakarta: PT Pradnya Paramita.Terjemahan dari Polymer Chemistry.

[21] Liu CF, Ren JL, Xu F, Liu JJ, Sun JX, Sun RC. 2006. Isolation and characterization of cellulose obtain from ultrasonic irradiated sugarcane bagasse. Jour of Agric Food Chem. 54(16):5742-8.

[22] Wang N, Ding E, Rongshi C. 2007. Thermal degradation behaviors of spherical cellulose nanocrystals with sulfate groups. Polymers 48:34863493.

Doi:10.1016/j.polymer.2007.03.062

[23] Zhang M, Qi W, Liu R, Su R, Wu S, He Z. 2010. Fractionating lignocellulose by formic acid: characterization of major components. Biomass and Bioen. 34: 525-532.

[24] Khan A, Khan RA, Salmieri S, Tien CL, Riedl B, Bouchard J, Chauve G, Tan V, Kamal MR, Lacroix M. 2012. Mechanical and barrier properties of nanocrystalline cellulose reinforced chitosan based nanocomposite films. Carbohyd Polym. 90:1601- 1608. Doi:10.1016/j.carbpol.2012.07.037

[25] Milovanovic S, Markovic D, Aksentijevic K, Stojanovic DB, Ivanovic J, Zizovic I. 2016. Application of cellulose acetate for controlled release of thymol. Carbohyd Polym. doi:10.1016/j.carbpol.2016.03.093

[26] Waheed S, Ahmad A, Khan SM, Gul S, Jamil T, Islam A, Hussain T. 2014. Synthesis, characterization, permeation and antibacterial properties of cellulose acetate/polyethylene glycol membranes modified with chitosan. Desalin 351: 59-69

[27] Castro C, Zuluaga R, Putaux JL, Caroa G, Mondragon I, Ganan P. 2011.Structural characterization of bacterial cellulose produced by gluconacetobacter swingsii $s p$ from Colombian agroindustrial wastes. Carbohyd Polym. 84: 96-102

[28] Barud HS, Araujo JAM, Santos DB, Assuncao RMN, Meireles CS, Cerqueira DA 2008. Thermal behavior of cellulose acetate produced from homogeneous acetylation of bacterial cellulose. Thermoch Act 471: 61-69 
[29] Pushpamalar V, Langford SJ, Ahmad M, Lim YY. 2006. Optimization of reaction conditions for preparing carboxymethylcellulose from sago waste. Carbohyd Polym.64:312-318

[30] Lee KY, Quero F, Blaker JJ, Hill CAS, Eichhorn SJ, Bismarck A. 2011. Surface only modification of bacterial cellulose nanofibers with organic acids. Cellul. 18: 595-605.

[31] Elanthikal S, Gopala KU, Varghese S, Guthrie JI. 2010. Cellulose microfibres produces from banana plant wastes: Isolation and Characterization. Carbohyd Polym. 80:852-859.

[32] Bhattacharya D, Germinario LT, Winter WT. 2008. Isolation, preparation and characterization of cellulose microfibers obtained from bagasse. Carbohyd Polym. 73:371377. 